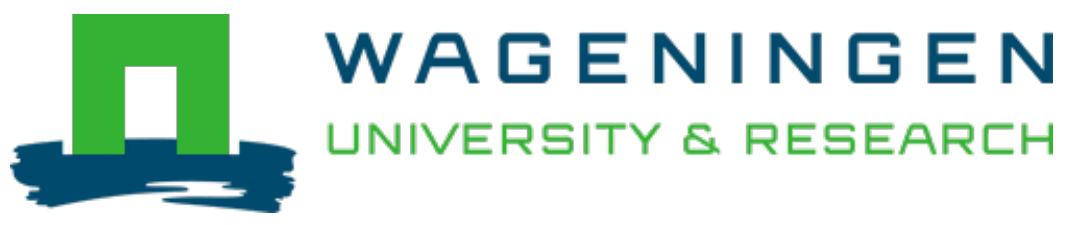

\title{
Ring width and vessel features of the mangrove Excoecaria agallocha L. depend on salinity in the Sundarbans, Bangladesh
}

\section{Dendrochronologia}

Siddique, Mohammad Raqibul Hasan; Zuidema, Pieter A.; Sass-Klaassen, Ute; Chowdhury, Md

Qumruzzaman

https://doi.org/10.1016/j.dendro.2021.125857

This publication is made publicly available in the institutional repository of Wageningen University and Research, under the terms of article $25 \mathrm{fa}$ of the Dutch Copyright Act, also known as the Amendment Taverne. This has been done with explicit consent by the author.

Article 25 fa states that the author of a short scientific work funded either wholly or partially by Dutch public funds is entitled to make that work publicly available for no consideration following a reasonable period of time after the work was first published, provided that clear reference is made to the source of the first publication of the work.

This publication is distributed under The Association of Universities in the Netherlands (VSNU) 'Article $25 \mathrm{fa}$ implementation' project. In this project research outputs of researchers employed by Dutch Universities that comply with the legal requirements of Article $25 \mathrm{fa}$ of the Dutch Copyright Act are distributed online and free of cost or other barriers in institutional repositories. Research outputs are distributed six months after their first online publication in the original published version and with proper attribution to the source of the original publication.

You are permitted to download and use the publication for personal purposes. All rights remain with the author(s) and / or copyright owner(s) of this work. Any use of the publication or parts of it other than authorised under article $25 \mathrm{fa}$ of the Dutch Copyright act is prohibited. Wageningen University \& Research and the author(s) of this publication shall not be held responsible or liable for any damages resulting from your (re)use of this publication.

For questions regarding the public availability of this publication please contact openscience.library@wur.nl 


\title{
ORIGINAL ARTICLE
}

\section{Ring width and vessel features of the mangrove Excoecaria agallocha $\mathrm{L}$. depend on salinity in the Sundarbans, Bangladesh}

\author{
Mohammad Raqibul Hasan Siddique ${ }^{\mathrm{a}, \mathrm{b}}$, Pieter A. Zuidema ${ }^{\mathrm{a}}$, Ute Sass-Klaassen ${ }^{\mathrm{a}}$, \\ Md. Qumruzzaman Chowdhury ${ }^{c, *}$ \\ ${ }^{\text {a }}$ Forest Ecology and Forest Management group, Wageningen University \& Research, P.O. Box 47, 6700AA, Wageningen, the Netherlands \\ ${ }^{\mathrm{b}}$ Forestry and Wood Technology Discipline, Khulna University, Khulna, 9208, Bangladesh \\ ${ }^{\mathrm{c}}$ Department of Forestry and Environmental Science, Shahjalal University of Science and Technology, Sylhet, 3114, Bangladesh
}

\section{A R T I C L E I N F O}

\section{Keywords:}

Bangladesh

Dendrochronology

Excoecaria agallocha

Mangroves

Salinity

Sundarbans

\begin{abstract}
A B S T R A C T
The Bangladesh Sundarbans is the largest continuous mangrove in the world that providing crucial environmental services, particularly related to coastal protection and livelihoods of millions of people. However, anthropogenic disturbances, diseases infestation and environmental changes including sea level rise (SLR) and fresh-water flux into the delta are threatening the Sundarbans and other mangrove ecosystems worldwide. Protection of mangrove ecosystems requires knowledge on factors that mainly drive growth and vitality of tree species to evaluate which consequences can be expected from, mainly hydrology-related, environmental changes. In this study, we assessed the nature and periodicity of tree rings in Excoecaria agallocha, a wide spread mangrove species in the Bangladesh Sundarbans. We also analysed the influence of climatic factors, such as precipitation, temperature and vapor pressure deficit (VPD), and river discharge, as a proxy of salinity on ring width (RW) and vessel features, such as mean vessel area (MVA) and mean vessel density (MVD). E. agallocha forms distinct tree-ring boundary that characterized by a narrow (2-4 cells wide) band of radially flattened fibres. The RW as well as the MVA and MVD are crossdatable. The RW is mainly driven by salinity which is influenced by freshwater inputs through precipitation during monsoon along with river discharge January to April. The MVA and MVD responded to similar seasons and months as RW, but mostly with opposite signs in MVD. The results suggest that fresh water inputs through precipitation and river discharge positively influence the radial growth of $E$. agallocha in the Sundarbans. The RW and vessel features can be used as proxies to explore the growth dynamics of this species, especially in relation to global environmental changes.
\end{abstract}

\section{Introduction}

Globally mangroves are very important ecosystems that providing coastal protection, coastal fisheries, land formation, nursery and breeding ground to marine organisms, and ecotourism (Lee et al., 2014; Himes-Cornell et al., 2018; Dasgupta et al., 2019), as well as sustaining human lives and livelihoods (Abdullah et al., 2016). In addition, mangroves are imperative for carbon sequestration (Ragavan et al., 2019; Rahman et al., 2021). Sundarbans $\left(10014 \mathrm{~km}^{2}\right)$, the largest single block of mangrove in the world, is located along the coast of Bangladesh (59\%) and India. Considering its unique ecosystem value, in terms of biological diversity and ecosystem services, the Bangladesh Sundarbans was declared as Ramsar site in 1992 and part of the forest (23\%) as World Heritage Site in 1997 (Gopal and Chauhan, 2006). However, this ecosystem is threatened by increasing anthropogenic disturbances, diseases infestation and environmental changes like many other mangroves in the world (Gilman et al., 2008; Mukherjee et al., 2014). Besides, climate change and sea level rise (SLR) are influencing the growth of many tree species in the Sundarbans (Chowdhury et al., 2016a; Maxwell et al., 2018). Anticipated climate change and SLR may alter population structure and species composition in this ecosystem in future (Ghosh et al., 2019; Sarker et al., 2021). Studying the driving factors behind long-term mangrove growth provides important information on ecosystem functioning and the vulnerability of mangrove species. Based on this direct management options to mitigate the impact of future environmental changes can be developed.

Long-term data on tree growth is essential for understanding changes in natural forests and useful for forest management (Worbes and

\footnotetext{
* Corresponding author.

E-mail address: qumrul-for@sust.edu (Md.Q. Chowdhury).
} 
Schöngart, 2019). Detection of tree age and estimates of radial growth rate for woody species are usually carried out by applying indirect methods, including periodic measurements of tree diameter in forest inventories usually from permanent sample plots (PSPs, Groenendijk et al., 2014). In the Sundarbans, forest inventories have been carried out periodically since 1926 to quantify forest stocks and for understanding forest dynamics (Iftekhar and Saenger, 2008). However, these inventories were not conducted at the same plots, and therefore estimations of species-specific tree age and growth rate is problematic. Since 1986, 120 PSPs have been established in the Sundarbans (Rahman, 1994) to obtain growth and demographic data e.g., age, growth rate, natural regeneration and survival. Even though these PSPs are effective in forest stock and diversity assessment (Sarker et al., 2016, 2019), accurate tree age and growth rate estimation from the PSPs is still challenging due to lack of systematic monitoring, such as all trees are not properly tagged and periodic diameter measurements are not documented for the respective trees (Chowdhury et al., 2016b). Therefore, retrospective studies of tree growth using tree-ring analysis is an option for accurate and faster estimation of tree age and growth rate for understanding growth dynamics, in response to changing environmental factors.

Mangrove species have received least momentum in dendrochronological studies due to the assumption that no distinct annual rings are formed in the highly dynamic intertidal growing conditions (Rao et al., 1987; Sun and Suzuki, 2000; Srivastava and Suzuki, 2001). However, meanwhile annual ring formation has been proved for some important mangrove species (e.g., Rhizophora mangle L., R. mucronata Lam., Laguncularia racemosa (L.) C.F. Gaertn, Heritiera fomes Buch.-Ham. and Sonneratia apetala Buch.-Ham. (Menezes et al., 2003; Verheyden et al., 2004; Estrada et al., 2008; Robert et al., 2011; Chowdhury et al., 2008, 2016a, 2016b; Souza et al., 2016; Maxwell et al., 2018; Rahman et al., 2020). Like in most species in (sub)tropical regions, the formation of distinct tree rings in mangrove species is attributed to the occurrence of a seasonal climate, characterized by one distinct dry and wet season, and also the seasonal variation in soil salinity (Chowdhury et al., 2008; Robert et al., 2011). The impact of soil salinity, which is related to freshwater flux into the system, leads to complex hydrological conditions in mangrove ecosystems which can affect growth of trees, even in the same area in different ways (Rahman et al., 2020). Despite influencing distinctness of the tree rings, also the timing of tree-ring formation can be affected by local differences in driving factors which in turn can lead to a reduced common signal in ring-width series even within a species (Menezes et al., 2003; Verheyden et al., 2004; Groenendijk et al., 2014). Thus, working with a mangrove species from different areas requires anatomical characterization of ring boundaries using a standard protocol (IAWA Committee, 1989; Tarelkin et al., 2016), and testing the periodicity of ring formation.

Including time series of wood anatomical features, i.e., mean vessel (MVA), vessel area and/or vessel density (MVD), can lead to additional information on growth determining factors if these features are influenced by other, e.g. more seasonal environmental factors than ring width (RW) (Verheyden et al., 2005; Ohashi et al., 2014; Islam et al., 2019). Vessel features are known to be sensitive intra-annual indicators of seasonal changes in hydrology (Verheyden et al., 2005; Schmitz et al., 2006), which in turn affects the hydraulic conductivity in trees. In mangroves, long-term changes in MVA and MVD across the radius can reflect associated temporal variations in soil-water salinity (Verheyden et al., 2005), as salinity determines the possibility of the tree to absorb sufficient water to support physiological processes (Jiang et al., 2017). Thus, understanding variation in vessel features in tree rings of mangroves can accomplish information on climate-growth relationships as gained from RW only especially to study hydrology driven tree responses.

Excoecaria agallocha L. (Euphorbiaceae) is a widely distributed mangrove species in the Indo-Malaysian and Indo-West Pacific region (Reef and Lovelock, 2015), but it occurs at high densities and considered as the second major species in the Sundarbans (Hossain et al., 2015; Sarker et al., 2016). Its wide distribution can be relevant for long-term assessment of the ecological amplitude of this important mangrove species through studying its performance under different environmental conditions. Earlier studies reported that this species produces distinct tree rings (InsideWood, 2004; Wheeler, 2011). Here, we present an evaluation of dendrochronological potential of E. agallocha in the Sundarbans, Bangladesh. In this study, we first characterize the tree-ring structure and test their periodicity along with statistical quality of ring width (RW) and vessel features (MVA and MVD) of E. agallocha. In a second step, we analyse the influence of climatic factors, such as precipitation, temperature and vapor pressure deficit (VPD) and river discharge on time series of RW and vessel features to evaluate which factors mainly drive the growth of $E$. agallocha in its complex environment.

\section{Materials and methods}

\subsection{Study area and climate}

The study was conducted in the Bangladesh Sundarbans $\left(6017 \mathrm{~km}^{2}\right)$ which is located $\left(21^{\circ} 30^{\prime}-22^{\circ} 30^{\prime} \mathrm{N}, 89^{\circ} 00^{\prime}-89^{\circ} 55^{\prime} \mathrm{E}\right)$ at the GangesBrahmaputra estuary (Fig. 1A). It covers $69 \%$ of the area, and remaining areas are water bodies, such as rivers, small streams and canals (Wahid et al., 2007). The soil is composed of silty-clay-loam with an elevation of 0.9-2.1 m above the mean sea level (Iftekhar and Islam, 2004). A major portion of this forest is inundated by the tide twice a day and the water level is related to the combined effects of the seawater tides in the Bay of Bengal and freshwater input from the Ganges river. Based on spatial variations in salinity, the forest can be divided into three areas: hyposaline (eastern and north-eastern regions), mesosaline (central and southern regions) and hypersaline (western and south-western regions) zone (Siddiqi, 2001; Rahman et al., 2021). The salinity of water in all three areas decreases rapidly with the increase of freshwater flow and precipitation during the monsoon (June-September), and increases steadily after reduced freshwater flow during the post-monsoon (October-November), when also precipitation is decreasing in winter (December-February) and in the following pre-monsoon (March-May, Fig. 1B). Therefore, the river discharge data was used as a proxy of salinity due to unavailability of long-term temporal scale salinity data in the Sundarbans (Anwar and Takewaka, 2014; Rahman et al., 2020).

Heritiera fomes and E. agallocha are the two dominant tree species in Bangladesh Sundarbans. E. agallocha often occurs as a monospecific type, and sometimes in association with $H$. fomes and Ceriops decandra (Griff.) Ding Hou (Iftekhar and Saenger, 2008). It is a moderate light demanding and fast growing species with high ability to colonize in open and degraded habitats (Siddiqi, 2001). Sarker et al. (2016) reported that E. agallocha is widely distributed in the Sundarbans except land-ward side. They also predicted that the distribution range of this light-demanding species may increase in future, as natural and anthropogenic disturbances will increase the occurrence of canopy gaps at $0.05 \%$ per year (Iftekhar and Islam, 2004). E. agallocha is deciduous in nature but the leafless period is short varying from mid February to mid April (Rahman and Islam, 2015), with leaf shedding being not simultaneous but rather in a patchy form.

The climate of the Sundarbans is monsoonal (Fig. 1C) and $71 \%$ of the mean annual precipitation occurs during the monsoon (Chowdhury et al., 2016a). The monsoon is preceded by a hot and humid pre-monsoon with sporadic rainfall that followed by a post-monsoon and a dry winter. The mean annual precipitation is $1600 \mathrm{~mm}$ and the mean relative humidity throughout the year ranges from 69 to $83 \%$. The mean temperature in pre-monsoon, monsoon, post-monsoon and dry winter is $29,30,26$ and $20^{\circ} \mathrm{C}$, respectively (Fig. 1C). 

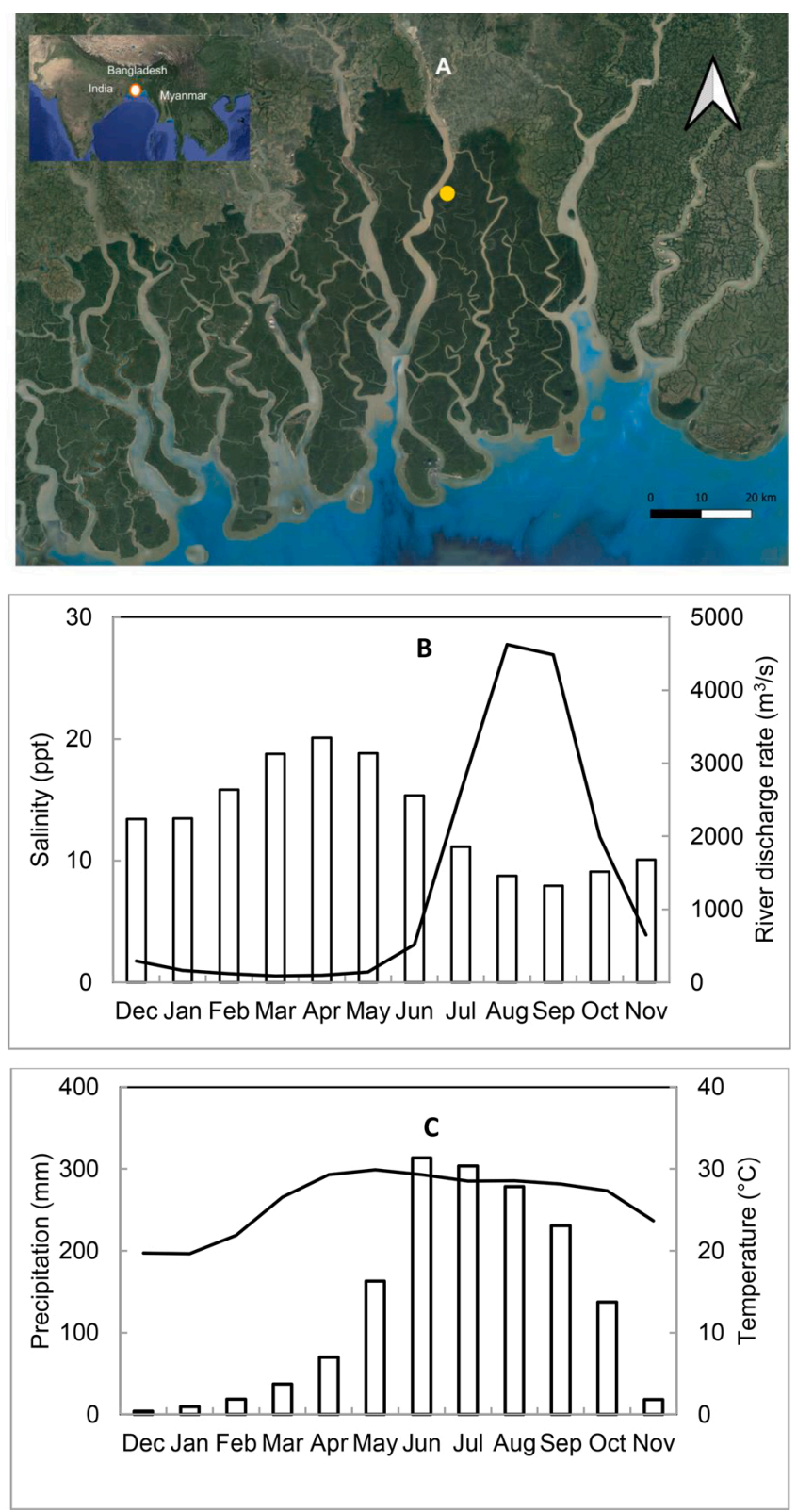

Fig. 1. Sampling location (yellow circle) in the Sundarbans (A). Monthly mean water salinity (1995-1997) and mean river discharge (1965-2000) in the Sundarbans were obtained from Bangladesh Water Development Board; vertical bars and solid line indicate salinity and river discharge, respectively (B). Monthly mean precipitation and temperature from nearby station (Khulna) of the study area (1962-2013) were obtained from Bangladesh Meteorological Department; vertical bars and solid line indicate precipitation and temperature, respectively (C). Dry winter (December-February), pre-monsoon (March-May), monsoon (June-September) and post-monsoon (October-November). (For interpretation of the references to colour in this figure legend, the reader is referred to the web version of this article).

\subsection{Detection of periodicity in ring formation}

We did pinning experiment to test the tree ring characters before sampling for ring width (RW) and vessel features study. In first step, 3 E. agallocha trees with foliage were selected for a cambial marking experiment and tagged for identification in the next year. Even though E. agallocha is distributed in most of the areas of the Sundabans, the present forest types (Iftekhar and Saenger, 2008) and habitat suitability maps (Sarker et al., 2016) show that E. agallocha prefers the low saline areas, and thus sampling was done in this site. Moreover, due to huge anthropogenic and natural (e.g., storms, erosion, sedimentation and inundation) disturbances, the pinning trees were selected in an accessible and protected zone where tree missing chance is low and the tagged trees could easily be identified. In second step, 10 visually healthy trees (avoiding mechanically and insect damage or infestation with disease) ranging in diameter (DBH) between 5 and $20 \mathrm{~cm}$ were randomly selected for stem disc collection for RW and vessel features study. Due to an ongoing moratorium, which prevents destructive sampling in the Sundarbans (Hossain et al., 2019), we could only select a small number of sample trees for this baseline study.

For pinning experiment, three trees were marked in January $6^{\text {th }} 2013$ at $1.3 \mathrm{~m}$ above the ground level, using a hypodermic needle (18 G; 1.2 mm diameter) and the cambial marked stem discs were collected one year later, on 1 st April 2014, when trees are assumed to be in cambial rest under high salinity during pre-monsoon. The location of cambial marking was easily detectable due to presence of a lenticel-like bark structure which was formed in response to the cambial wounding (Verheyden et al., 2004; Chowdhury et al., 2016b). The cambium marked discs were sanded using a sanding machine (ranging from 100 to 800 grit) until the cambial marking wounds and the neighboring tissue became visible.

Small blocks $(15 \times 15 \mathrm{~mm})$ were extracted from the discs. Transversal micro-thin sections with a thickness of $10 \mu \mathrm{m}$ were cut using a sliding microtome (WSL, Birmensdorf, Switzerland). The sections were first stained with $0.1 \%$ safranin, washed with an ethanol series $(50,75$, 96 and 100\%), mounted on microscope slides and covered with a cover glass. After observation of micro-thin sections under a light microscope (Leica DM 2500, Germany), the images were taken (4x magnification) using a Leica camera (DFC 320) connected to the light microscope. The wood anatomy and tree-ring boundaries were characterized according to IAWA Committee (1989), adapted by Tarelkin et al. (2016). Wound tissue was carefully observed to locate the exact position of the cambial cells at the time of marking and assess the structure of the xylem which was formed after marking.

\subsection{Time-series analyses of ring width and vessel features}

\subsubsection{Sample preparation and measurement of $R W$ and vessel features}

Stem discs were sanded using a sanding machine with sanding paper (ranging from 100 to 800 grit) for RW study. Ring boundaries were identified under a stereomicroscope and marked on two opposite radii of the sanded disc using a pencil. When selecting the two radii, parts with reaction wood and other growth anomalies, like wedging or likely entirely missing rings, were omitted to facilitate correct dating of each ring. The stem discs were scanned after marking.

For vessel features study, transversal micro-thin sections with a thickness of $10 \mu \mathrm{m}$ were cut from pith to bark along the two radii per sample (see method section 2.2). Images were taken from pith to bark with successive measuring frames of $3 \mathrm{~mm}$ at $2.5 \mathrm{x}$ magnification under a light microscope. Successive images along the radius were stitched using a software. The RW and vessel features i.e., mean vessel area (MVA, $\mu \mathrm{m}^{2}$ ) and mean vessel density (MVD, $\mathrm{mm}^{-2}$ ) were measured using Fiji ImageJ software (Schindelin et al., 2012). The MVA and MVD were calculated in each ring.

\subsubsection{Chronology development}

The RW series of the two radii per tree were crossdated visually, first within trees and then between trees to assign the correct calendar year to each ring (Schweingruber, 1988). Finally, a statistical check was done using the COFECHA program (Holmes, 1983; Grissino-Mayer, 2001). The same procedure was applied for developing the vessel chronologies. To minimize the variation owing to individual growth pattern, e.g., due to ontogenetic trends, both in RW and vessel features, all individual series were filtered by a cubic spline function (Cook and Peters, 1981). Each individual series was detrended by fitting a negative exponential curve with 30 year stiffness and 50\% cutoff using the ARSTAN program 
(Cook and Holmes, 1984). To eliminate most of the first-order autocorrelation, autoregressive modeling was performed on each detrended RW as well as MVD and MVA series. Finally all detrended series were averaged into residual chronologies for RW, MVD and MVA using a biweight robust mean. The statistical quality of the RW, MD and MVA vessel chronologies was evaluated on the basis of detrended individual series using parameters commonly used in dendrochronology (Wigley et al., 1984; Briffa and Jones, 1990): the mean inter-series correlation (Rbar), expressed population signal (EPS), mean sensitivity (MS) and autocorrelation (AR1).

\subsection{Correlation with climatic factors and upstream river discharge}

The influences of precipitation, temperature and vapor pressure deficit (VPD) on chronologies were determined using the program DendroCLIM2002 (Biondi and Waikul, 2004), which uses bootstrapped confidence intervals to estimate the significance of a correlation. Temperature, precipitation, and humidity data (1962-2013) of Khulna station were obtained from the Bangladesh Meteorological Department which is located $60 \mathrm{~km}$ away from the study site. The vapor pressure deficit (VPD) was calculated using local station data following the equations: $\mathrm{VPD}=[(100-\mathrm{RH}) / 100] * \mathrm{SVP}$, where SVP (saturated vapor pressure $)=0.610 * \exp \left[\left(17.27^{*} \mathrm{~T}\right) /(\mathrm{T}+237.3)\right], \mathrm{T}=$ temperature and $\mathrm{RH}=$ relative humidity (Murray, 1967). The salinity in the Sundarbans is primarily regulated by the combined effects of tides in the Bay of Bengal and freshwater inputs from the Ganges trough the Gorai river, and thus there is an inverse relation between river water discharge and salinity in the Sundarbans (Islam and Gnauck, 2011). Due to the lack of long-term direct measurements of salinity we used river discharge data (1965-2000) of the Bangladesh Water Development Board from the Gorai river (the largest river connecting the Sundarbans to the Ganges) as a proxy for salinity Sundarbans (Anwar and Takewaka, 2014; Rahman et al., 2020) for the correlation (Pearson) analysis with chronologies. Due to seasonal climate, the correlation analysis was done with seasonal data, in addition to monthly data.

\section{Results}

\subsection{Tree-ring anatomy and periodicity in ring formation}

A cambial marker was formed in the xylem as a response of the wounding by pinning (Fig. 2A). The inserted needle induced a puncture canal in the xylem which resulted in crushed cells, and amorphous zone and oxidized xylem (see Smith, 1988). The xylem was oxidized around the puncture canal and parenchymatous wound tissue was formed above the layer of crushed cells. Both marked trees produced smaller vessels with a higher vessel density in the restored xylem after wounding (Fig. 2B). Moreover, gummy substances were deposited in some vessels of the oxidized xylem. The cambial marked samples showed that a distinct ring was formed between the date of pinning and the moment of sample collection which can be identified on the polished stem disc as well as on the micro-thin sections under a microscope (Fig. 2). The ring boundaries are defined by a narrow band (2-4 cells wide) of radially flattened fibres (Fig. S1). The mean radial diameter of flattened fibres $(6.80 \pm 1.61 \mu \mathrm{m})$ at ring boundary was two-fold lower than radial fibre diameter $(13.67 \pm 3.25 \mu \mathrm{m})$ in rest part of the tree ring. However, tree-ring anomalies, mostly wedging rings and missing rings were also present in the studied samples. The wood of E. agallocha is diffuse-porous. The MVA and MVD showed inter-annual variations throughout the radius that corresponded with the number of tree rings of the respected tree (Fig. S2). Crossdating of RW was successful for 9 out of 10 trees, and confirms the annual nature of tree rings in E. agallocha.

\subsection{Tree age and statistical characteristics of $R W$ and vessel chronologies}

The age of E. agallocha trees varied from 20 to 51 year and the mean radial growth rate was $2.12 \pm 0.82 \mathrm{~mm} \mathrm{year}^{-1}$. The MVA was $7570 \pm$ $4129 \mu \mathrm{m}^{2}$ and MVD was $8 \pm 4 \mathrm{~mm}^{-2}$, respectively. The RW showed a steady decrease ontogenetic trend from pith to bark, whereas the MVA had an increasing MVA, and the MVD showed a decreasing trend with increasing age. In general the MVA $\left(7570 \pm 3129 \mu \mathrm{m}^{2}\right)$ and MVD $(8 \pm 3$

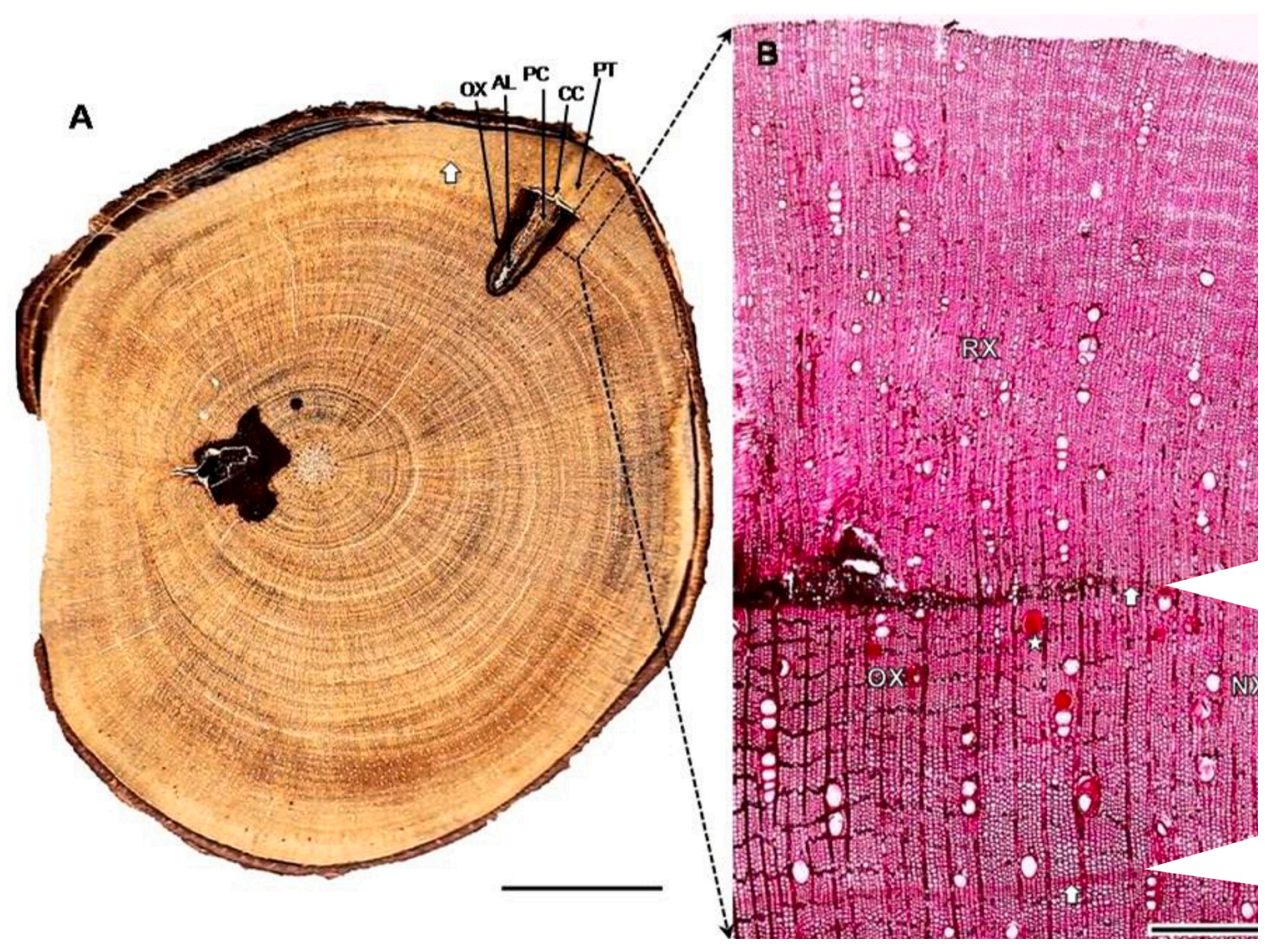

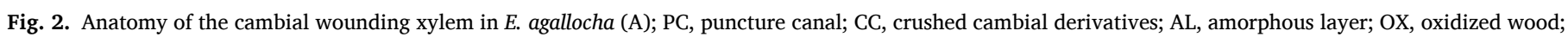

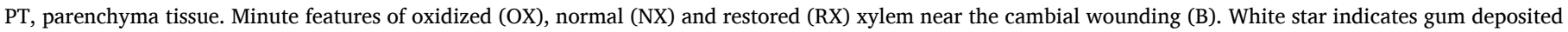
vessel and white arrow indicates the tree ring. Scale bar $=1 \mathrm{~cm}(\mathrm{~A})$ and $500 \mu \mathrm{m}(\mathrm{B})$. 
vessel $\mathrm{mm}^{-2}$ ) were found to be low in E. agallocha which can be expected in a mangrove species and is within the range obtained by Mariam et al. (2012), who found 6-21 vessels $\mathrm{mm}^{-2}$ and vessel area $7491-39388 \mu \mathrm{m}^{2}$.

The RW series of crossdated samples yielded in a site chronology spanning from 1962 to 2013 (51 years, Fig. 3A). Similarly, chronologies were developed for MVA and MVD (Figs. 3B, C). The time-series of RW contained a stronger common signal than those of vessel chronologies (Table 1). The EPS value of RW series was 0.81 which is close to the critical value of 0.85 (Wigley et al., 1984), but the EPS value of all the vessel features were lower than the critical value (Table 1 ). The RW chronology revealed high environmental sensitivity (0.41) compared to previously established thresholds (low: 0.10-0.19, intermediate: $0.20-0.29$ and high: $\geq 0.30$, respectively (Grissino-Mayer, 2001). However, the mean sensitivity was low in vessel chronologies compared to RW (Table 1). The mean inter-series correlation (Rbar) had low values
Table 1

Characteristics of chronologies of ring width (RW) and vessel features (mean vessel area, MVA and mean vessel density, MVD) of E. agallocha.

\begin{tabular}{|c|c|c|c|}
\hline Parameters & RW & $\begin{array}{l}\text { Chronology } \\
\text { MVA }\end{array}$ & MVD \\
\hline Mean \pm SD & $\begin{array}{l}2.12 \pm 0.82 \mathrm{~mm} \\
\text { year }^{-1}\end{array}$ & $\begin{array}{l}7570 \pm 3129 \\
\mu \mathrm{m}^{2}\end{array}$ & $\begin{array}{l}8 \pm 3 \text { vessel } \\
\mathrm{mm}^{-2}\end{array}$ \\
\hline $\begin{array}{l}\text { Time span } \\
\text { (year) }\end{array}$ & $1962-2013$ & $1962-2013$ & $1962-2013$ \\
\hline Rbar & 0.28 & 0.10 & 0.18 \\
\hline EPS & 0.81 & 0.34 & 0.61 \\
\hline MS & 0.42 & 0.14 & 0.16 \\
\hline AR1 & 0.32 & 0.13 & 0.14 \\
\hline
\end{tabular}

SD, standard deviation; Rbar, inter-series correlation; EPS, expressed population signal; MS, mean sensitivity; AR1, autocorrelation.
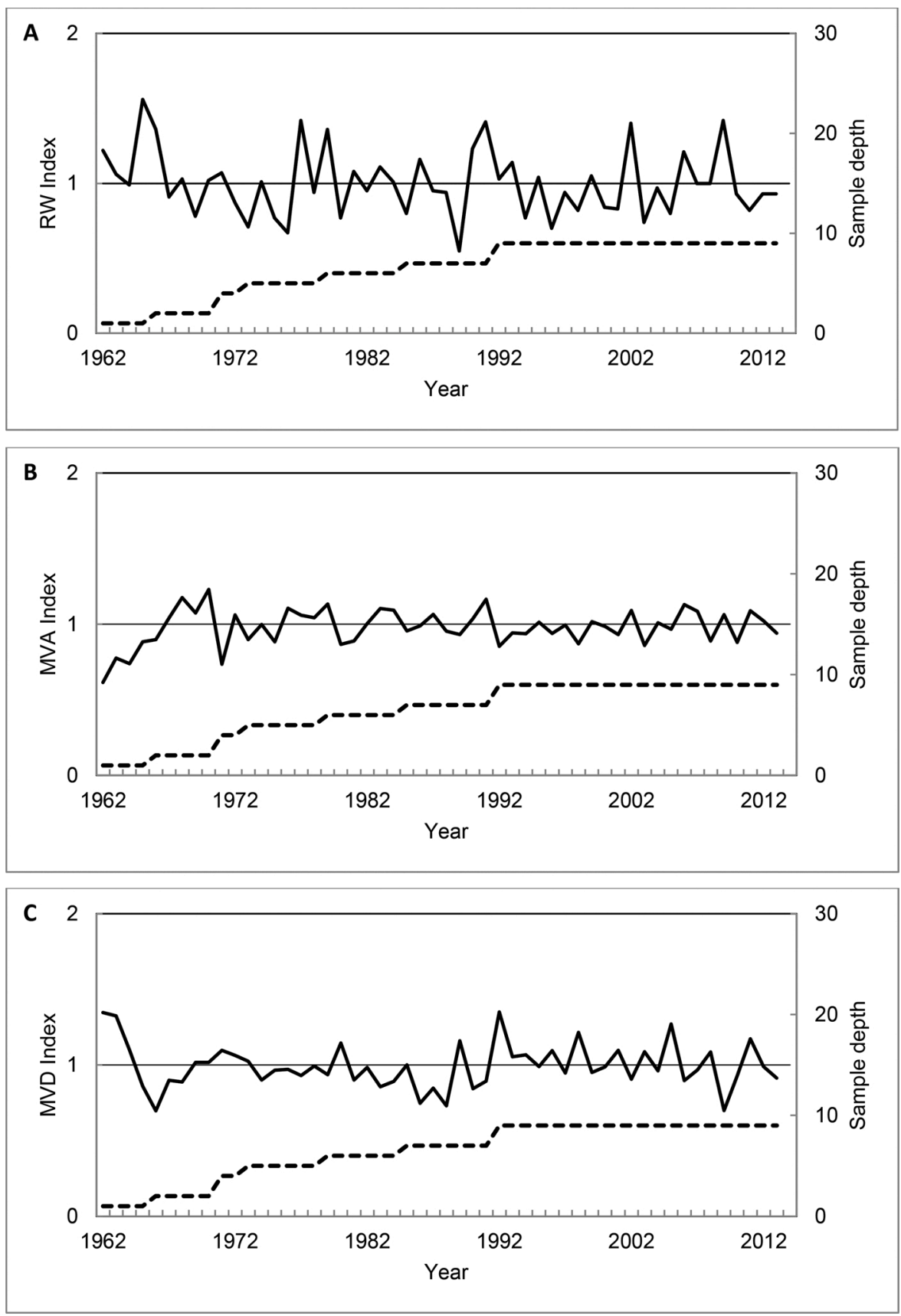

Fig. 3. The chronologies of tree-ring width, RW (A) and vessel parameters, such as MVA, mean vessel area (B) and MVD, mean vessel density (C) indices of E. agallocha. Dotted lines indicate the number of sample trees included in the chronologies. 
mainly caused by the short time spans of the series and the previous year growth did not significantly affect the features (very low AR1values). The RW series showed a relatively higher year-to-year variation (higher MS values) than MVD and MVA series (Table 1). The MVA positively correlated with RW chronology but the correlation was not significant $(r$ $=0.21, p>0.05$ ). The MVA and MVD chronology showed a significant negative correlation $(r=-0.50, p<0.05)$. The RW also showed a significant inverse correlation with MVD chronology ( $r=-0.43, p<0.05)$, and suggesting that these chronologies may contain opposite environmental signals, as described for other angiosperms (Oladi et al., 2014; Islam et al., 2019). Therefore, this study highlights the relevance of using a multi-variable time-series approach.

\subsection{Influence of climatic factors and river discharge on $R W$ and vessel features}

The amount of monsoon precipitation, specifically in the months June until August, showed a significant positive effect on RW $(p<0.05)$ (Fig. 4A). The river discharge during the dry winter months of January and February, and pre-monsoon (March-May) was also significantly beneficial for formation of wide rings in E. agallocha (Fig. 4B). The MVA had similar response as RW to precipitation (Fig. 4A). In case of river discharge, the correlations of MVA were not significant. In general, MVA and MVD respond to similar seasons and months as RW, but mostly with opposite signs in MVD (Fig. 4 A\&B). The MVD showed a significant negative correlation with precipitation of August and positive in dry winter (December-February). The river discharge showed a strong negative correlation with MVD in post-monsoon of the previous year (Fig. 4B). Temperature and VPD had non-significant correlation with the chronologies of RW and vessel features (Fig. S3).

\section{Discussion}

\subsection{E. agallocha forms distinct annual rings}

The studied stem discs displayed distinct tree rings which are marked by a band (2-4 cells wide) of radially flattened fibers (Figs. 2, S1). Earlier studies also reported that tree rings in this species are distinct (InsideWood, 2004; Wheeler, 2011). However, tree-ring anomalies, mostly wedging rings and missing rings are also present like in other mangroves
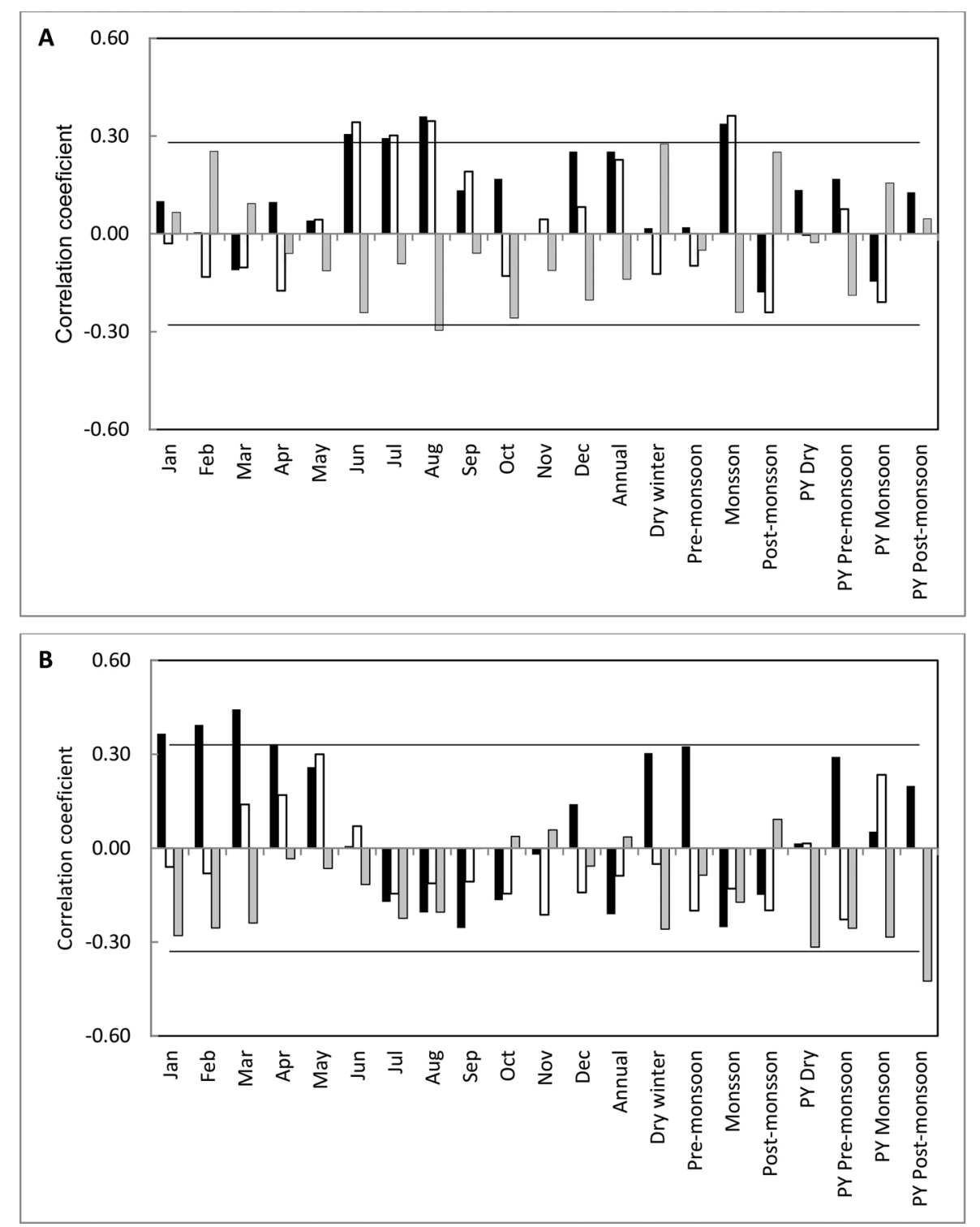

Fig. 4. Correlations coefficients of ring width (RW, black bars), mean vessel area (MVA, white bars) and mean vessel density (MVD, grey bars) chronologies with precipitation (A) and river discharge (B). Upper and lower horizontal lines indicate the significant level at $p<0.05$. Dry winter (December-February), pre-monsoon (March-May), monsoon (June-September) and post-monsoon (October-November). PY, previous year. 
species (Chowdhury et al., 2016a, b; Rahman et al., 2020). Apart from site, the tree-ring anomalies, such as wedging and missing rings might be associated with position of wood samples in trees (Tarelkin et al., 2016), and phases of low growth rates or stem asymmetry in mangrove trees (Chowdhury et al., 2016b). The asymmetrical stems are common in mangroves because of growth stress that might be related to inundation, sedimentation, erosion, seasonal storms and anthropogenic disturbances (Ellison et al., 2000; Robert et al., 2011). Such kinds of tree-ring anomalies are also frequent in different tropical species (Trouet et al., 2010; De Ridder et al., 2013). Despite tree-ring anomalies, 9 out of 10 trees could be visually and statistically crossdated which affirm the annual nature of tree rings in this species.

Being deciduous nature, E. agallocha sheds leaves for a short period that varies from mid February to mid April (Rahman and Islam, 2015) during the peak of salinity which is associated with low precipitation and river discharge (Figs. 1B, C). It is generally assumed that the cambial dormancy in tropical trees is induced some time before leaf shedding (Borchert, 1999). The precipitation data indicates that the precipitation is very low (nearly of $35 \mathrm{~mm}$ ) from December to April and increases from May to September (Fig. 1C). Afterwards, it decreases from October. In addition, the up-steam river flow decreases more than $75 \%$ from December to April (Mirza, 1998) and the salinity increases from 80 to $90 \%$ in the Sundarbans (Islam and Gnauck, 2011). High salinity and low precipitation might trigger cambial dormancy in E. agallocha which might be reflected in leaf shedding (Rahman and Islam, 2015). It is also reported that a dry season (monthly precipitation is less than $60 \mathrm{~mm}$ ) enduring more than 3 months is sufficient to invoke dormancy in cambial to trigger annual ring formation in the tropics (Worbes, 1995; Trouet et al., 2012). These studies also demonstrate that radial growth is mainly influenced by the seasonal climate along with salinity variations in the Sundarbans. The presence of a distinct dry winter season associated with high salinity may attribute to ring formation in mangroves also suggested by other studies (Menezes et al., 2003; Estrada et al., 2008; Robert et al., 2011).

The mean radial growth of E. agallocha is $2.12 \pm 0.82 \mathrm{~mm}_{\text {year }}{ }^{-1}$ which lower than $S$. apetala in similar salinity zone $(3.11 \pm 1.23 \mathrm{~mm}$ year $\left.^{-1}\right)$, and much higher than $H$. fomes $\left(1.17 \pm 0.16 \mathrm{~mm}_{\text {year }}{ }^{-1}\right)$ in the Sundarbans (Chowdhury et al., 2016a; Rahman et al., 2020). S. apetala is a light demanding species and E. agallocha is a moderate light demanding species, whereas $H$. fomes is a shade tolerant species (Siddiqi, 2001). Apart from ecological guilds, the growth rate variation could be attributed by salinity difference as it varies spatially in the Sundarbans (Islam and Gnauck, 2011; Sarker et al., 2019). The species-specific growth differences can also occur even within shorter site distances in the Sundarbans, which indicates the importance of the specific environmental settings especially related to salinity for the growth of mangrove species (Rahman et al., 2020).

\subsection{Vessel features can benefit time-series analyses in E. agallocha}

Although we expected that inter-annual variation in vessel features, such as MVA and MVD are related to RW and can be explained mainly in terms of water availability, there are yet only few tropical species for which vessel features are considered to be directly affected by water availability (Verhyden et al., 2005, Bhattacharyya et al., 2007; Ohashi et al., 2014; Islam et al., 2019). Periodic inundation and salinity causes a low soil-water potential (Reef and Lovelock, 2015), which might further decrease during the dry and pre-monsoon in the Sundarbans, due to decrease amount of precipitation and river discharge and an increase of evaporation attributable to increased temperature. As a consequence, reduced water availability for trees might induce inter-annual variation in vessel features. To avoid the risk of cavitation in times of low water availability, trees tend to form more and smaller vessels to maintain hydraulic safety during water stress (Tyree and Zimmermann, 2002; Meinzer et al., 2009; Mencuccini et al., 2015). The MVD showed an inverse relation $(r=-0.50, p<0.01)$ with MVA, and this trade-off is considered to be an hydraulic safety measure (Verhyden et al., 2005; Schmitz et al., 2006; Madrid et al., 2014). Ontogeneic trends in E. agallocha are following common patterns with smaller vessels in higher density close to the pith and increasingly larger and wider spaced vessels towards the bark, consistent with other mangrove species (Schmitz et al., 2006; Chowdhury et al., 2008).

The statistical parameters indicate that the magnitude of the common signals varied among the chronologies (Table 1). Due to high variability in vessel size and density these time series are known to show weaker intra- and inter-tree correlations in comparison to the more integrating variable RW (García-González et al., 2016; Islam et al., 2019). The low first-order autocorrelation (Table 1) indicates the lower influence of external factors from the previous year to the current year's growth. Similarly, the lower autocorrelation values are evident in other mangrove species in the Sundarbans (Chowdhury et al., 2016a; Rahman et al., 2020). The average Rbar is low in each chronology, but this metric is known to vary among the species, regions and climates (Grissino-Mayer, 2001), and are usually low for tropical trees (De Ridder et al., 2013). Along with good visual synchronization, similar low average Rbar and EPS indicates the existence of common signals and poses the suitability of the three chronologies for dendrochronological studies.

\subsection{Salinity drives radial growth of E. agallocha}

The climate-growth relationship indicates that radial growth is positively influenced by the precipitation during monsoon $(p<0.05)$, especially in June, July and August (Fig. 4A) because the monsoonal fresh water influx lowers the soil salinity. Similarly, the monsoonal precipitation strongly influences tree growth in $H$. fomes and $S$. apetala in the Sundarbans (Chowdhury et al., 2016a; Maxwell et al., 2018; Rahman et al., 2020). The positive effect of above-average precipitation on radial growth was also found by Menzes et al. (2003) and Krauss et al. (2007) for mangrove species growing under a seasonal climate. This seasonal change in salinity is also related to diameter growth of Avicenia alba Blume, and increment mainly in the wet season (Komiyama et al., 2019). Due to higher water availability the stomatal conductance increases carbon assimilation during the wet season in R. mucronata in Kenyan mangroves (Mwangi et al., 1999). Negative correlation of MVD in August $(p<0.05$ ) indicates that $E$. agallocha adjusts higher growth by increasing vessel size and reducing vessel density due to higher precipitation. The vessel size increases with the availability of water in wet season due to a high turgor pressure in developing cells enabling rapid cell expansion (Sass and Eckstein, 1995; Tyree, 1997). The soil salinity starts to increase after reduction of precipitation and river discharge during dry season (December-February) and reaches its peak in transition (pre-monsoon) season (Wahid et al., 2007) which is associated with leafless time. The absence or low influential correlations during these periods with RW series also explain that high salinity might inhibit the growth.

The river discharge is another important source of fresh water input in the Sundarbans. Earlier studies highlighted that decrease of upstream river discharge increases the salinity which negatively affects the population dynamics in the Sundarbans (Wahid et al., 2007; Sarker et al., 2019). The river discharge shows significant influences on RW from January to April ( $p<0.05$, Fig. 4B). The positive correlation indicates that increase of river discharge decrease the soil salinity which may influence growth reaction of trees as a pre-effect in the beginning of monsoon. Chen and Ye (2014) also found vigorous diameter growth at low salinity in E. agallocha seedlings (up to $10 \mathrm{ppt}$ ) and reduced growth under moderate salinity (after $25 \mathrm{ppt}$ ). It suggests that lower salinity stimulates growth of E. agallocha, especially in monsoon. The MVD is negatively influenced by river discharge of the previous year during post-monsoon which suggests a prolongation of the previous growing season of trees. 


\section{Conclusion and perspectives}

This study serves to highlight the value of E. agallocha for dendrochronology in Bangladesh Sundarbans, and is the first of its kind. The tree rings are distinct which are annual in nature. In addition, the vessel features (i.e., MVA and MVD) also showed periodicity using crossdating analysis. We found that growth of this species is mainly driven by freshwater inputs through precipitation during the monsoon along with river discharge in dry and pre-monsoon season. It seems that the combined effect of river discharge and precipitation determines salinity which is the major environmental cue triggering periodicity in tree-ring formation. The exact timing of tree-ring formation can be determined by seasonal cambial analysis along with dendrometer measurements. This study however provides a solid basis for tree age and growth rate determination of $E$. agallocha. Moreover, the RW and vessel features in different growth conditions (salinity) can be used for understanding ecology of this species and dynamics of the mangrove ecosystem, especially in response of environmental changes including SLR.

\section{Funding}

This study was funded by Netherlands Fellowship Programme (NFP) under NUFFIC (Grant number: NFP-2012004011/2013).

\section{Declaration of Competing Interest}

The authors report no declarations of interest.

\section{Acknowledgements}

We are thankful to Ellen Boerstra-Wilderink (WUR) for her supports during laboratory works on wood anatomy and microscopic imaging. We thank Bangladesh Forest Department for the permission and Sundarbans East Forest Division for helping us during the fieldworks. We acknowledge Forestry and Wood Technology Discipline, Khulna University for logistic supports. We acknowledge two anonymous reviewers for their critical reviews and valuable comments on the earlier versions of the manuscript.

\section{Appendix A. Supplementary data}

Supplementary material related to this article can be found, in the online version, at doi:https://doi.org/10.1016/j.dendro.2021.125857.

\section{References}

Abdullah, A.N.M., Stacey, N., Garnett, S.T., Myers, B., 2016. Economic dependence on mangrove forest resources for livelihoods in the Sundarbans, Bangladesh. For. Policy Econ. 64, 15-24. https://doi.org/10.1016/j.forpol.2015.12.009.

Anwar, M.S., Takewaka, S., 2014. Analyses on phenological and morphological variations of mangrove forests along the southwest coast of Bangladesh. J. Coast. Conserv. 18, 339-357. https://doi.org/10.1007/s11852-014-0321-4.

Bhattacharyya, A., Eckstein, D., Shah, S.K., Chaudhary, V., 2007. Analyses of climatic changes around Perambikulum, South India, based on earlywood mean vessel area of teak. Curr. Sci. 93, 1159-1164.

Biondi, F., Waikul, K., 2004. DENDROCLIM 2002: a C++ program for statistical calibration of climate signals in tree-ring chronologies. Comp. Geosci. 30, 303-311. https://doi.org/10.1016/j.cageo.2003.11.004.

Borchert, R., 1999. Climatic periodicity, phenology, and cambium activity in tropical dry forest trees. IAWA J. 20, 239-247. https://doi.org/10.1163/22941932-90000687.

Briffa, K.R., Jones, P.D., 1990. Basic chronology statistics and assessment. In: Cook, E.R. Kairiukstis, L.A. (Eds.), Methods of Dendrochronology: Applications in the Environmental Sciences. Kluwer, Boston, pp. 137-152.

Chen, Y., Ye, Y., 2014. Effects of salinity and nutrient addition on mangrove Excoecaria agallocha. PLoS One 9, e93337.

Chowdhury, M.Q., Schmitz, N., Verheyden, A., Sass-Klaassen, U., Koedam, N., Beeckman, H., 2008. Nature and periodicity of growth rings in two Bangladeshi mangrove species. IAWA J. 29, 265-276. https://doi.org/10.1163/2294193290000185.

Chowdhury, M.Q., De Ridder, M., Beeckman, H., 2016a. Climatic signals in tree rings of Heritiera fomes Buch.-Ham. In the Sundarbans, Bangladesh. PLoS One 11, e0149788. https://doi.org/10.1371/journal.pone.0149788.
Chowdhury, M.Q., Kitin, P., De Ridder, M., Delvaux, C., Beeckman, H., 2016b. Cambial dormancy induced growth rings in Heritiera fomes Buch.- Ham.: a proxy for exploring the dynamics of Sundarbans, Bangladesh. Trees. 30, 227-239. https://doi.org/ 10.1007/s00468-015-1292-2.

Cook, E.R., Holmes, R.L., 1984. Program ARSTAN User Manual: Laboratory of Tree Ring Research. University of Arizona, Tucson.

Cook, E.R., Peters, K., 1981. The smoothing spline: a new approach to standardizing forest interior tree-ring width series for dendroclimatic studies. Tree-ring Bull. 41, 45-55.

Dasgupta, S., Islam, M.S., Huq, M., Huque Khan, Z., Hasib, M.R., 2019. Quantifying the protective capacity of mangroves from storm surges in coastal Bangladesh. PLoS One 14 (3), e0214079. https://doi.org/10.1371/journal.pone.0214079.

De Ridder, M., Trouet, V., den Bulcke, J.V., Hubau, W., Acker, J.V., Beeckman, H., 2013. A tree-ring based comparison of Terminalia superb climate-growth relationships in West and Central Africa. Trees. 27, 1225-1238. https://doi.org/10.1007/s00468013-0871-3.

Ellison, A.M., Mukherjee, B.B., Karim, A., 2000. Testing patterns of zonation in mangroves: scale dependence and environmental correlates in the Sundarbans of Bangladesh. J. Ecol. 88, 813-824. https://doi.org/10.1046/j.13652745.2000.00500.x.

Estrada, G.C.D., Callado, C.H., Soares, M.L.G., Lisi, C.S., 2008. Annual growth rings in the mangrove Laguncularia racemosa (Combretaceae). Trees. 22, 663-670.

García-González, I., Souto-Herrero, M., Campelo, F., 2016. Ring porosity and earlywood vessels: a review on extracting environmental information through time. IAWA J. 37, 295-314. https://doi.org/10.1163/22941932-20160135.

Ghosh, M.K., Kumar, K., Langat, P.K., 2019. Geospatial modeling of the inundation levels in the Sundarbans mangrove forests due to the impact of sea level rise and identification of affected species and regions. Geomat. Nat. Haz. Risk. 10, 1028-1046. https://doi.org/10.1080/19475705.2018.1564373.

Gilman, E.L., Ellison, J., Duke, N.C., Field, C., 2008. Threats to mangroves from climate change and adaptation options: a review. Aquatic Bot. 89, 237-250. https://doi.org/ 10.1016/j.aquabot.2007.12.009.

Gopal, B., Chauhan, M., 2006. Biodiversity and its conservation in the Sundarban mangrove ecosystem. Aquat. Sci. 68, 338-354. https://doi.org/10.1007/s00027006-0868-8.

Grissino-Mayer, H.D., 2001. Evaluating crossdating accuracy: a manual and tutorial for the computer program COFECHA. Tree-ring Res. 57, 205-221.

Groenendijk, P., Sass-Klaassen, U., Bongers, F., Zuidema, P.A., 2014. Potential of treering analysis in a wet tropical forest: a case study on 22 commercial tree species in Central Africa. For. Ecol. Manage. 323, 65-78. https://doi.org/10.1016/j. foreco.2014.03.037.

Himes-Cornell, A., Pendleton, L., Atiyah, P., 2018. Valuing ecosystem services from blue forests: a systematic review of the valuation of salt marshes, sea grass beds and mangrove forests. Ecosyst. Serv. 30, 36-48. https://doi.org/10.1016/j. ecoser.2018.01.006.

Holmes, R.L., 1983. Computer-assisted quality control in tree-ring dating and measurement. Tree-Ring Bull. 43, 69-78.

Hossain, M., Siddique, M.R.H., Saha, S., Abdullah, S.M.R., 2015. Allometric models for biomass, nutrients and carbon stock in Excoecaria agallocha of the Sundarbans, Bangladesh. Wetlands Ecol. Manage. 23, 765-774. https://doi.org/10.1007/s11273015-9419-1.

Hossain, M., Siddique, M.R.H., Rubaiot Abdullah, S.M., Costello, L., Matieu, H., Iqbal, M. Z., Akhter, M., 2019. Which option best estimates the above-ground biomass of mangroves of Bangladesh: pantropical or site- and species-specific models? Wetlands Ecol. Manage. 27, 553-569. https://doi.org/10.1007/s11273-019-09677-0.

IAWA Committee, 1989. IAWA list of microscopic features for hardwood identification. IAWA Bull 10, 219-332 n.s.

Iftekhar, M.S., Islam, M.R., 2004. Managing mangroves in Bangladesh: a strategy analysis. J. Coast. Conserv. 10, 139-146. https://doi.org/10.1652/14000350(2004) 010[0139:MMIBAS]2.0.CO;2.

Iftekhar, M.S., Saenger, P., 2008. Vegetation dynamics in the Bangladesh Sundarbans mangroves: a review of forest inventories. Wetlands Ecol. Manage. 16, 291-312. https://doi.org/10.1007/s11273-007-9063-5.

InsideWood, 2004. InsideWood onwards. Published on the Internet. http://insidewood.li b.ncsu.edu/search (last visited on 20 April 2021).

Islam, S.N., Gnauck, A., 2011. Water salinity investigation in the Sundarbans rivers in Bangladesh. Int. J. Water. 6, 74-91.

Islam, M., Rahman, M., Bräuning, A., 2019. Long-term wood anatomical time series of two ecologically contrasting tropical tree species reveal differential hydraulic adjustment to climatic stress. Agri. For. Met. 265, 412-423. https://doi.org/ 10.1016/j.agrformet.2018.11.037.

Jiang, G.F., Goodale, U.M., Liu, Y.Y., Hao, G.Y., Cao, K.F., 2017. Salt management strategy defines the stem and leaf hydraulic characteristics of six mangrove tree species. Tree Physiol. 37, 389-401. https://doi.org/10.1093/treephys/tpw131.

Komiyama, A., Poungparn, S., Umnouysin, S., Rodtassana, C., Pravinvongvuthi, T., Noda, T., Kato, S., 2019. Occurrence of seasonal water replacement in mangrove soil and the trunk growth response of Avicennia alba related to salinity changes in a tropical monsoon climate. Ecol. Res. 34, 428-439. https://doi.org/10.1111/14401703.12005.

Krauss, K.W., Keeland, B.D., Allen, J.A., Ewel, K.C., Johnson, D.J., 2007. Effects of season, rainfall, and hydrogeomorphic setting on mangrove tree growth in Micronesia. Biotropica. 39, 161-170. https://doi.org/10.1111/j.17447429.2006.00259.x.

Lee, S.Y., Primavera, J.H., Dahdouh-Guebas, F., McKee, K., Bosire, J.O., Cannicci, S., Diele, K., Fromard, F., Koedam, N., Marchand, C., Mendelssohn, I., Mukherjee, N., 
Record, S., 2014. Reassessment of mangrove ecosystem services. Glob. Ecol. Biogeogr. 23, 726-743. https://doi.org/10.1111/geb.12155.

Madrid, E.N., Armitage, A.R., López-Portillo, J., 2014. Avicennia germinans (black mangrove) vessel architecture is linked to chilling and salinity tolerance in the Gulf of Mexico. Front. Plant Sci. 5, 503. https://doi.org/10.3389/fpls.2014.00503.

Mariam, H., Mohiuddin, M., Alam, A.H.M.J., 2012. Anatomical Studies of Twenty Five Mangrove Species of the Sundarbans Bangladesh. Bulletin 18. Wood anatomy series, Forest botany division, BFRI, Chittagong.

Maxwell, J.T., Harley, G.L., Rahman, A.F., 2018. Annual growth rings in two mangrove species from the Sundarbans, Bangladesh demonstrate linkages to sea-level rise and broad-scale ocean-atmosphere variability. Wetlands 38, 1159-1170. https://doi. org/10.1007/s13157-018-1079-5.

Meinzer, F.C., Johnson, D.M., Lachenbruch, B., McCulloh, K.A., Woodruff, D.R., 2009. Xylem hydraulic safety margins in woody plants: coordination of stomatal control of xylem tension with hydraulic capacitance. Funct. Ecol. 23, 922-930. https://doi. org/10.1111/j.1365-2435.2009.01577.x.

Mencuccini, M., Minunno, F., Salmon, Y., Martínez-Vilalta, J., Hölttä, T., 2015. Coordination of physiological traits involved in drought-induced mortality of woody plants. New Phytol. 208, 396-409. https://doi.org/10.1111/nph.13461.

Menezes, M., Berger, U., Worbes, M., 2003. Annual growth rings and long-term growth patterns of mangrove trees from the Bragança peninsula, North Brazil. Wetlands Ecol. Manage. 11, 233-242. https://doi.org/10.1023/A:1025059315146.

Mirza, M.M.Q., 1998. Diversion of the Ganges water at Farakka and its effects on salinity in Bangladesh. Environ. Manage. 22, 711-722. https://doi.org/10.1007/ s002679900141.

Mukherjee, N.M., Sutherland, W.J., Khan, M.N.I., Berger, U., Schmitz, N., DahdouhGuebas, F., Koedam, N., 2014. Using expert knowledge and modeling to define mangrove composition, functioning, and threats and estimate time frame for recovery. Ecol. Evol. 4 (11), 2247-2262. https://doi.org/10.1002/ece3.1085.

Murray, F.W., 1967. On the computation of saturation vapor pressure. J. Appl. Meteorol. Climatol. 6, 203-204. https://doi.org/10.1175/1520-0450(1967)006<0203: OTCOSV $>2.0 . \mathrm{CO} ; 2$.

Mwangi, M.T., Kinyamario, J.I., Van Speybroeck, D., 1999. Photosynthesis and related physiological processes in two mangrove species, Rhizophora mucronata and Ceriops tagal, at Gazi Bay, Kenya. African J. Ecol. 37, 180-193. https://doi.org/10.1046/ j.1365-2028.1999.00167.x.

Ohashi, S., Okada, N., Abdul Azim, A.A., Siripatanadilok, S., Veenin, T., Yahya, A.Z., Nobuchi, T., 2014. Vessel feature changes as a tool for detecting annual rings in tropical trees. Trees. 28, 137-149. https://doi.org/10.1007/s00468-013-0936-3.

Oladi, R., Bräuning, A., Pourtahmasi, K., 2014. "Plastic" and "static" behavior of vessel anatomical features in Oriental beech (Fagus orientalis Lipsky) in view of xylem hydraulic conductivity. Trees 28, 493-502. https://doi.org/10.1007/s00468-0130966-x.

Ragavan, P., Sivakumar, K., Jayaraj, R.S.C., Mohan, P.M., Rana, T.S., 2019. Carbon storage potential of mangroves - are we missing the boat? Curr. Sci. 116, 889-891.

Rahman, M.A., 1994. Diseases and Disorders of Trees with Special Reference to Top Dying of Sundri in the Mangrove Forests in Sundarbans in Bangladesh. Integrated Resource Development of the Sundarbans Reserved Forest, p. 83. FAO/UNDP/BGD/ 84/056.

Rahman, M.M., Islam, S.A., 2015. Phenophases of five mangrove species of the Sundarbans of Bangladesh. Int. J. Bus. Soc. Sci. Res. 4, 77-82. http://www.ijbssr. com/currentissueview/14013130.

Rahman, M.S., Sass-Klaassen, U., Zuidema, P.A., Chowdhury, M.Q., Beeckman, H., 2020. Salinity drives growth dynamics of the mangrove tree Sonneratia apetala Buch. -Ham. In the Sundarbans, Bangladesh. Dendrochronologia. 62, 125711 https://doi.org/ 10.1016/j.dendro.2020.125711.

Rahman, M.S., Donoghue, D.N.M., Bracken, L.J., 2021. Is soil organic carbon underestimated in the largest mangrove forest ecosystems? Evidence from the Bangladesh Sundarbans. Catena. 200, 105159 https://doi.org/10.1016/j. catena.2021.105159.

Rao, R.V., Sharma, B., Chauhan, L., Dayal, R., 1987. Reinvestigations of the wood anatomy of Duabanga and Sonneratia with particular reference to their systematic position. IAWA Bull. (NS) 8, 337-345.

Reef, R., Lovelock, C.E., 2015. Regulation of water balance in mangroves. Ann. Bot. 115, 385-395. https://doi.org/10.1093/aob/mcu174.

Robert, E.M.R., Schmitz, N., Okello, J.A., Boeren, I., Beeckman, H., Koedam, N., 2011. Mangrove growth rings: fact or fiction? Trees. 25, 49-58. https://doi.org/10.1007/ s00468-010-0487-9.

Sarker, S.K., Reeve, R., Thompson, J., Paul, N.K., Matthiopoulos, J., 2016. Are we failing to protect threatened mangroves in the Sundarbans world heritage ecosystem? Sci. Rep. 6 https://doi.org/10.1038/srep21234.
Sarker, S.K., Matthiopoulos, J., Mitchella, S.N., Ahmed, Z.U., Al Mamun, M.B., Reevea, R., 2019. 1980s-2010s: the world's largest mangrove ecosystem is becoming homogeneous. Biolo. Conser. 236, 79-91. https://doi.org/10.1016/j. biocon.2019.05.011.

Sarker, S.K., Reeve, R., Matthiopoulos, J., 2021. Solving the fourth-corner problem: forecasting ecosystem primary production from spatial multispecies trait-based models. Ecol. Monogr. https://doi.org/10.1002/ecm.1454. Accepted Author Manuscript.

Sass, U., Eckstein, D., 1995. The variability of vessel size in beech (Fagus sylvatica L.) and its ecophysiological interpretation. Trees. 9, 247-252. https://doi.org/10.1007/ BF00202014.

Schindelin, J., Arganda-Carreras, I., Frise, E., Kaynig, V., Longair, M., Pietzsch, T. Preibisch, S., Rueden, C., Saalfeld, S., Schmid, B., 2012. Fiji: an open-source platform for biological-image analysis. Nat. Methods 9, 676-682. https://doi.org/10.1038/ nmeth.2019.

Schmitz, N., Verheyden, A., Beeckman, H., Kairo, J.G., Koedam, N., 2006. Influence of a salinity gradient on the vessel characters of the mangrove species Rhizophora mucronata. Ann. Bot. 98, 1321-1323. https://doi.org/10.1093/aob/mcl224.

Schweingruber, F.H., 1988. Tree Rings-basics and Applications of Dendrochronology. D. Reidel Publishing Company.

Siddiqi, N.A., 2001. Mangrove Forestry in Bangladesh. Institute of Forestry \& Environmental Sciences, University of Chittagong.

Smith, K.T., 1988. Wounding, compartmentalization, and treatment tradeoffs. J. Arnold Arbor. 14, 226-229.

Souza, B.T., Estrada, G.C.D., Soares, M.L.G., Callado, C.H., 2016. Occurrence of annual growth rings in Rhizophora mangle in a region with low climate seasonality. Annal. Brazilian Acad. Sci. 88, 517-525. https://doi.org/10.1590/00013765201620150009.

Srivastava, R., Suzuki, M., 2001. More fossil woods from the Palaeogene of northern Kyushu, Japan. IAWA J. 22, 85-105. https://doi.org/10.1163/22941932-90000271.

Sun, Q., Suzuki, M., 2000. Wood anatomy of mangrove plants in Iriomote Island of Japan: a comparison with mangrove plants from lower latitudes. Acta Phytotaxonomica et Geobotanica. 51, 37-55.

Tarelkin, Y., Delvaux, C., De Ridder, M., El Berkani, T., De Cannière, C., Beeckman, H., 2016. Growth-ring distinctness and boundary anatomy variability in tropical trees. IAWA J. 37 (2), 275-S277. https://doi.org/10.1163/22941932-20160134.

Trouet, V., Esper, J., Beeckman, H., 2010. Climate/growth relationships of Brachystegia spiciformis from the miombo woodland in south central Africa. Dendrochronologia 28, 161-171. https://doi.org/10.1016/j.dendro.2009.10.002.

Trouet, V., Mukelabai, M., Verheyden, A., Beeckman, H., 2012. Cambial growth season of brevi-deciduous Brachystegia spiciformis trees from South Central Africa restricted to less than four months. PLoS One 7, e47364.

Tyree, M.T., 1997. The cohesion-tension theory of sap ascent, current controversies. J. Exp. Bot. 48, 1753-1765. https://www.jstor.org/stable/23695741.

Tyree, M.T., Zimmermann, M.H., 2002. Xylem Structure and the Ascent of Sap, 2nd ed. Springer, Berlin, Heidelberg, Berlin.

Verheyden, A., Kairo, J.G., Beeckman, H., Koedam, N., 2004. Growth rings, growth ring formation and age determination in the mangrove Rhizophora mucronata. Ann. Bot. 94, 59-66. https://doi.org/10.1093/aob/mch115.

Verheyden, A., De Ridder, F., Schmitz, N., Beeckman, H., Koedam, N., 2005. Highresolution time series of vessel density in Kenyan mangrove trees reveal a link with climate. New Phytol. 167, 425-435. https://doi.org/10.1111/j.14698137.2005.01415.x.

Wahid, S.M., Babel, M.S., Bhuiyan, A.R., 2007. Hydrologic monitoring and analysis in the Sundarbans mangrove ecosystem, Bangladesh. J. Hydrol. 332, 381-395. https:// doi.org/10.1016/j.jhydrol.2006.07.016.

Wheeler, E.A., 2011. InsideWood - a web resource for hardwood anatomy. IAWA J. 32, 199-211. https://doi.org/10.1163/22941932-90000051.

Wigley, T.M.L., Briffa, K.R., Jones, P.D., 1984. On the average value of correlated time series, with applications in dendroclimatology and hydrometeorology. J. Climate Appl. Meteorol. 23, 201-213. https://doi.org/10.1175/1520-0450(1984) 023<0201:OTAVOC> 2.0.CO;2.

Worbes, M., 1995. How to measure growth dynamics in tropical trees: a review. IAWA J. 16, 337-351. https://doi.org/10.1163/22941932-90001424.

Worbes, M., Schöngart, J., 2019. Measures for sustainable forest management in the tropics - a tree-ring based case study on tree growth and forest dynamics in a Central Amazonian lowland moist forest. PLoS One 14 (8), e0219770. https://doi.org/ 10.1371/journal.pone.0219770. 